\title{
Graptolite faunas of the Llandovery "phtanites" at Les Fresnaies (Chalonnes-sur-Loire, southeastern Armorican Massif): Palaeontology and biostratigraphy
}

\author{
José Manuel PiçARRA, Michel Robardet, José TOMÁs OliveirA, Florentin PARIS \& \\ HUBERT LARDEUX
}

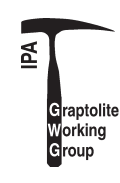

\begin{abstract}
In the SE of the Armorican Massif (France), the Ordovician-Silurian transition and the lower part of the Silurian are exposed at the locality Les Fresnaies at Chalonnes-sur-Loire. The Silurian graptolitic "phtanites" (black cherts) are richly fossiliferous. Detailed sampling allows a description of the graptolite faunas and a precise stratigraphical analysis of the succession that comprises the whole of the Rhuddanian and Aeronian stages. Both the Llandovery graptolite assemblages and the lithologies of Les Fresnaies are similar to those of other lower Silurian successions throughout peri-Gondwanan Europe, like Portugal, Spain, Sardinia, Bohemia, Germany and Carnic Alps, and in the Middle East (Jordan and Saudi Arabia). - Key words: Silurian, Armorican Massif, France, graptolites, biostratigraphy.
\end{abstract}

PiÇArra, J.M., Robardet, M., Oliveira, J.T., Paris, F. \& LARdeuX, H. 2009. Graptolite faunas of the Llandovery "phtanites" at Les Fresnaies (Chalonnes-sur-Loire, southeastern Armorican Massif): Palaeontology and biostratigraphy. Bulletin of Geosciences 84(1), 41-50 (5 figures). Czech Geological Survey, Prague. ISSN 1214-1119. Manuscript received July 20, 2008; accepted in revised form November 19, 2008; published online January 6, 2009; issued March 31, 2009.

José Manuel Piçarra, Laboratório Nacional de Energia e Geologia, Dep. de Geologia, Ap. 104, 7801-902 Beja, Portu gal; jose.picarra@ineti.pt. - Michel Robardet, 3 rue Anatole Le Braz F35830 Betton, France; michel.andree.robardet@orange.fr • José Tomás Oliveira, Laboratório Nacional de Energia e Geologia, Dep. de Geologia, Ap. 7586, 2720 Alfragide, Portugal; tomas.oliveira@ineti.pt. • Florentin Paris, Géosciences-Rennes, UMR 6118 du CNRS, Université de Rennes 1, 35042 Rennes, France; florentin.paris@ univ-rennes1.fr • Hubert Lardeux, Le Verger Beaucé F35520 Mélesse, France; hubert.lardeux@wanadoo.fr

The study of a new section in the so-called graptolitebearing "phtanites" (i.e. black cherts), exposed ca $300 \mathrm{~m}$ from the locality reported by Davy $(1895,1906)$ at Les Fresnaies (Chalonnes-sur-Loire, S.E. Armorican Massif), has recently shown (Piçarra et al. 2002) that the overturned succession comprised (in ascending stratigraphical order):

1. clast-bearing argillites, dated as Hirnantian by chitinozoans of the Tanuchitina elongata Biozone, corresponding to the Late Ordovician glaciomarine deposits (Robardet et al. 1994) known from most north-Gondwanan regions, 2. black shales and black cherts that yield a succession of graptolite assemblages indicating the whole Rhuddanian (including its basalmost part) and the Aeronian.

The present paper is based on a more complete sampling of the section and gives a more precise stratigraphical analysis of the succession.

The fossiliferous locality of Les Fresnaies, although known for more than a century (Davy 1895, 1906), has a special significance because the new section offers without doubt the most complete succession that can be observed in the Llandovery of the Ligerian Domain (Fig. 1), and there- fore is a reference for the whole southeastern part of the Armorican Massif.

The graptolites described here (numbers prefixed MHNN.P.) are deposited in the Museum d'Histoire Naturelle de Nantes.

\section{Geological setting}

The Variscan basement of the Armorican Massif (Fig. 1), has been dissected by major shear-zones: the North Armorican Shear Zone (NASZ) and the two branches (North and South) of the South Armorican Shear Zone (SASZ). The NASZ has no palaeogeographical significance as the pre-Carboniferous successions are very similar in the midand north-Armorican regions (Mid-North Armorican Domain of Paris \& Robardet 1977, 1994). The northern branch of the SASZ which separates the Mid-North Armorican Domain and the South Armorican Ligerian Domain (Cogné 1974, Dubreuil et al. 1989, Lardeux \& Cavet 1994) separates pre-Carboniferous Palaeozoic successions that 


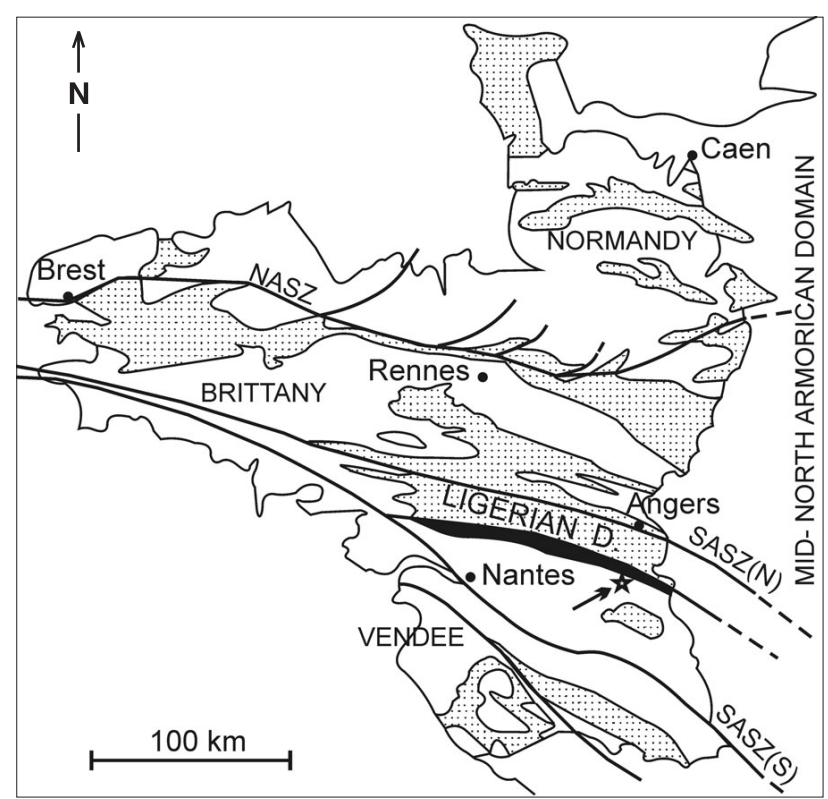

Figure 1. Geographical distribution of Palaeozoic strata (dotted areas) in the Armorican Massif (Ancenis Unit in black), with location of the studied graptolitic locality (black star). NASZ - North-Armorican Shear Zone; SASZ - South-Armorican Shear Zone; (N) - northern branch; (S) - southern branch

show important differences (Paris \& Robardet 1977, 1994; Robardet et al. 1994).

Within the Ligerian units of Saint-Julien-de-Vouvantes, Saint-Georges-sur-Loire and Ancenis, the pre-Carboniferous Palaeozoic rocks occur as small outcrops, dispersed within formations whose age remains uncertain in the first two units but is Early Carboniferous in the Ancenis Unit (Rivière 1977). The most satisfactory interpretation (Dubreuil 1980, 1986) is that these small outcrops are olisthostromes and olistholiths redeposited within Early Carboniferous basins.

In the Ancenis Unit, and in the other parts of the Ligerian
Domain, the original pre-Carboniferous Palaeozoic succession, reconstructed from the isolated outcrops, differs clearly from that of the Mid-North Armorican Domain, although both show North Gondwanan characteristics. The Ligerian succession does not show the shallow-water deposits that are so characteristic of the Mid-North Armorican Domain (e.g., the Lower Ordovician "Grès Armoricain" and the lowermost Devonian "Grès à Platyorthis monnieri"); it comprises more argillaceous lithologies, with more abundant pelagic faunas and benthic faunas that have strong affinities with those of the Barrandian rocks of the Czech Republic (Lardeux \& Cavet 1994).

The absence of any transitional area between the southern part of the Mid-North Armorican Domain and the Ligerian units, and their present juxtaposition along the Northern Branch of the South Armorican Shear Zone, indicates that the present situation was established during the Variscan Orogeny.

In the Ligerian units, the Silurian comprises numerous outcrops of graptolite-bearing "phtanites" which do not exist in the Mid-North Armorican Domain where the lithologies are different (Paris \& Robardet 1977, Lardeux et al. 1977). These "phtanites" are black siliceous rocks, of centimetric or decimetric bed thicknesses, intercalated with black shales. Under the microscope they appear as microquartzites sometimes with radiolarian remains. Their outcrops are always discontinuous, a few metres thick, and the relations with the surrounding rocks can never be seen clearly. These phtanites, their graptolite faunas and their Llandovery age have been known for a long time (Barrois 1892, Davy 1895, Philippot 1950).

\section{Les Fresnaies locality}

The outcrops of Les Fresnaies at Chalonnes-sur-Loire (Fig. 1), in the southeastern part of the Ancenis Unit (i.e. in

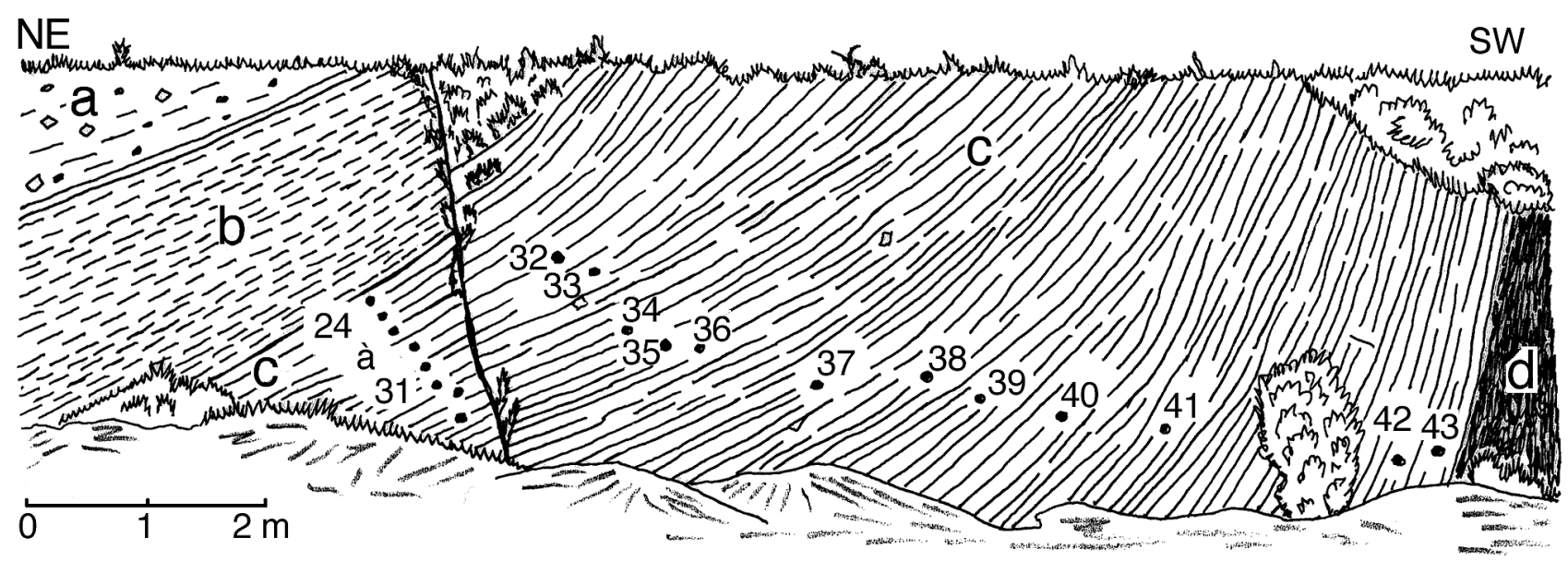

Figure 2. Uppermost Ordovician and Lower Silurian (Llandovery) section at Les Fresnaies. a - clast-bearing siltstones, b-grey shales, c - black cherts and black shales, $\mathrm{d}$ - tectonised levels. 


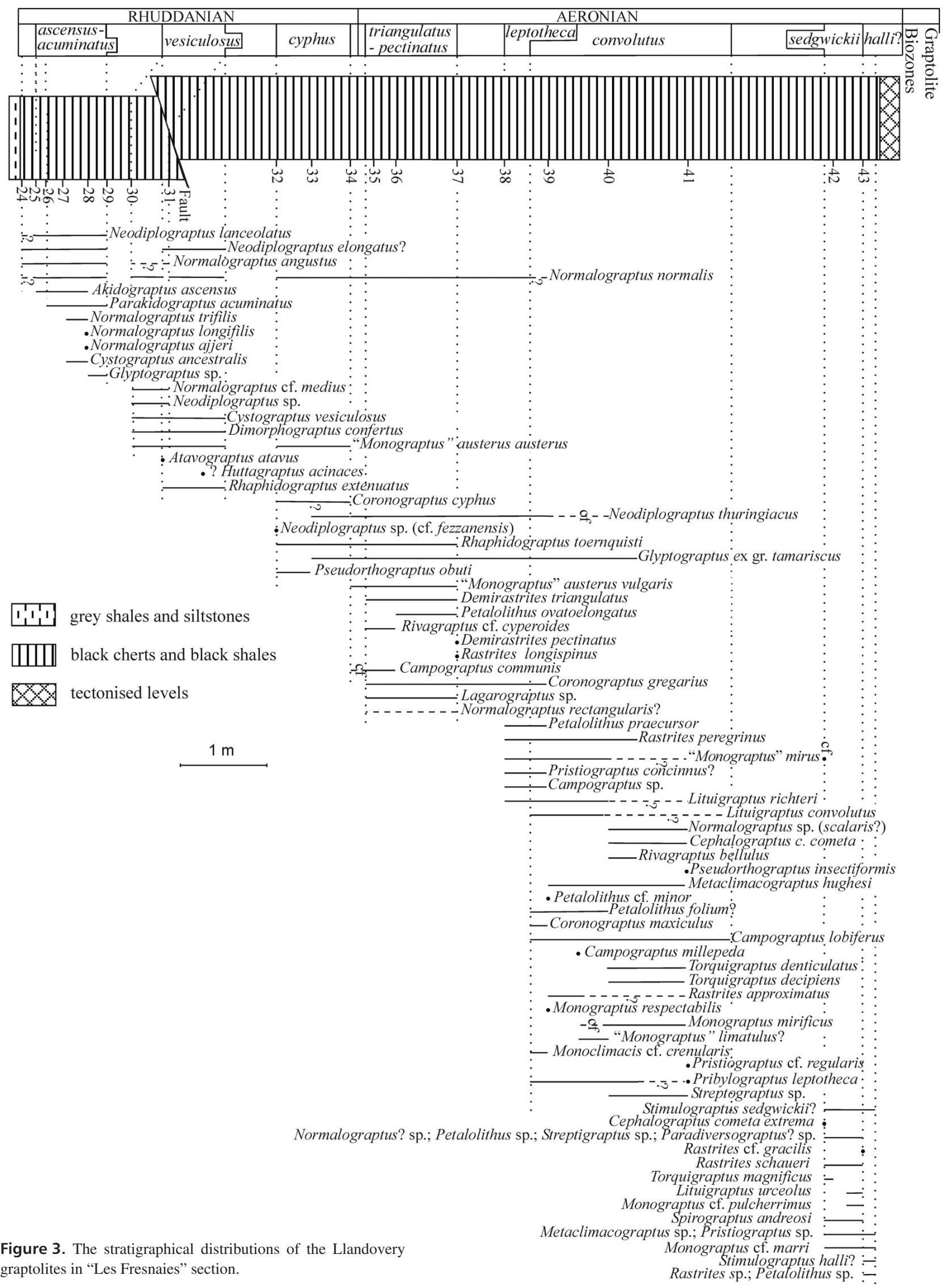


the southernmost part of the Ligerian Domain) are the most famous graptolite bearing sections of the Armorican Massif, owing to the abundance, diversity and relatively good preservation of the graptolites. This locality was discovered by Davy $(1895,1906)$ and the graptolite faunas were first studied by Barrois and later revised on several occasions. In the most recent revision, Philippot (1950) identified 17 species but considered that the fauna was the same in the different beds, with no possibility of subdivision into distinct biozones, and that, taken as a whole, it was indicative of the "middle" part of the Llandovery (Aeronian and basal Telychian in modern terminology). The collection of graptolites studied by Philippot (1950) is not accessible at present, due to reorganization of the building where they are stored in the University Rennes I. In this historical locality of Les Fresnaies, however, only part of the Llandovery sequence was exposed.

New data have been obtained from an artificial section (Fig. 2) excavated in a new commercial area to the SE of Chalonnes-sur-Loire (Lambert coordinates $\mathrm{X}=366,1$ $\mathrm{Y}=265,25$, topographic map $1: 50,000$ Chalonnes-surLoire XIV-22). Although the rock sequence is overturned, the exposure, already described by Piçarra et al. (2002), is exceptional because it exposes a sequence of phtanites (about $10 \mathrm{~m}$ ) much thicker than the 2 or $3 \mathrm{~m}$ previously accessible in the natural exposures of the historical locality (Dubreuil 1986, p. 51) and shows clearly the contact with the late Ordovician glaciomarine diamictites. The phtanites and the intercalated black shales are well stratified and the whole sequence has yielded rather well preserved graptolites.

A first study (Piçarra et al. 2002) identified successive graptolite assemblages indicating the presence of the whole Rhuddanian, probably the whole Aeronian (in spite of some uncertain data in the middle part) and a level thought to correspond to the lower part of the Telychian.

Since that time, additional and more detailed sampling has been carried out and the graptolites collected allow a much more precise biostratigraphical analysis, based on additional records (Fig. 3). In the present paper we have retained the original numbering (level 24 to level 43) of the fossiliferous levels used in figures 3 and 4 of Piçarra et al. (2002).

It should be emphasized that the results obtained in this locality are considered as representative for the Silurian of the whole Ligerian Domain.

\section{Biostratigraphy}

\section{Akidograptus ascensus-Parakidograptus acuminatus Biozone}

The lowermost graptolites, Neodiplograptus lanceolatus? Štorch \& Serpagli, Neodiplograptus elongatus? Churkin \& Carter, Normalograptus angustus (Perner) and Normalograptus normalis? (Lapworth), were found $5 \mathrm{~cm}$ above the base of the phanites (level 24). Up to level 29, i.e. $1.1 \mathrm{~m}$ above their base, the phtanites contain assemblages including Parakidograptus acuminatus (Nicholson) (Fig. 4A), Akidograptus ascensus Davies (Fig. 4B), Neodiplograptus lanceolatus (Fig. 4G), Neodiplograptus elongatus?, Normalograptus angustus, Normalograptus trifilis (Manck) (Fig. 4D), Normalograptus normalis? (Fig. 4E), Normalograptus longifilis (Manck), Normalograptus ajjeri (Fig. 4F), Cystograptus ancestralis Štorch (Fig. 4C) and Glyptograptus sp. This assemblage characterizes the Para kidograptus acuminatus Biozone which was until recently, the lowermost graptolite biozone of the Rhuddanian (and thus of the Llandovery Series and of the Silurian System).

Akidograptus ascensus has its first appearance $0.2 \mathrm{~m}$ above the base of the phtanites (level 25), i.e. slightly before Parakidograptus acuminatus which is identified at $0.3 \mathrm{~m}$ above the base of these phtanites. Both species co-occur for $0.5 \mathrm{~m}$ up to level 29 (i.e., $0.8 \mathrm{~m}$ above the base of the phtanites). A similar small lag between the first appearance of these two species had been noted in Thuringia (Jaeger 1976, 1988), in the Ossa Morena Zone of Spain (Jaeger \& Robardet 1979), in Bohemia (Štorch 1986, 1994, 1996, 2006), Sardinia (Štorch \& Serpagli 1993), NE Russia (Koren' \& Sobolevskaya 1983) and China (Mu 1988, Chen et al. 2007 and references therein). This has led several authors to distinguish a separate Akidograptus ascensus Biozone below the Parakidograptus acuminatus Biozone (see discussion in Loydell 2007). It must be noted that a similar situation has been documented recently at Dob's Linn (Melchin 2004 and references therein), in the type section (GSSP) of the base of the Silurian System. The assemblage mentioned above includes the taxa that are the most important for biostratigraphy and that also occur in most north-Gondwanan regions, as in Bohemia where 15 species of biserial graptolites have been identified (Štorch 1994) in the combined Akidograptus ascensus-Parakidograptus acuminatus Biozone. Neodiplograptus

Figure 4. Graptolites of the Akidograptus ascensus-Parakidograptus acuminatus (A-G), Cystograptus vesiculosus (H-J), Coronograptus cyphus (K-M) and Demirastrites triangulatus-Demirastrites pectinatus (N, O) biozones. - A - Parakidograptus acuminatus, MHNN.P. 053268. - B - Akidograptus ascensus, MHNN.P. 053269. • C - Cystograptus ancestralis, MHNN.P. 053270. • D - Normalograptus trifilis, MHNN.P. 053271. - E - Normalograptus normalis?, MHNN.P. 053272. • F - Normalograptus ajjeri, MHNN.P. 053273. G - Neodiplograptus lanceolatus, MHNN.P. 053274. • H - Cystograptus vesiculosus, MHNN.P. 053275. • I - Atavograptus atavus, MHNN.P. 053276. • J - Dimorphograptus confertus, MHNN.P. 053277. • K - Glyptograptus ex gr. tamariscus, MHNN.P. 053278. • L - Coronograptus cyphus?, MHNN.P. 053279. • M - Monograptus austerus vulgaris, MHNN.P. 053280. $\bullet \mathrm{N}-$ Coronograptus gregarius, MHNN.P. 053281. $\bullet$ O - Petalolithus ovatoelongatus . All $\times 5$. 
José Manuel Piçarra et al. • Graptolite faunas of the Llandovery "phtanites", Armorican Massif

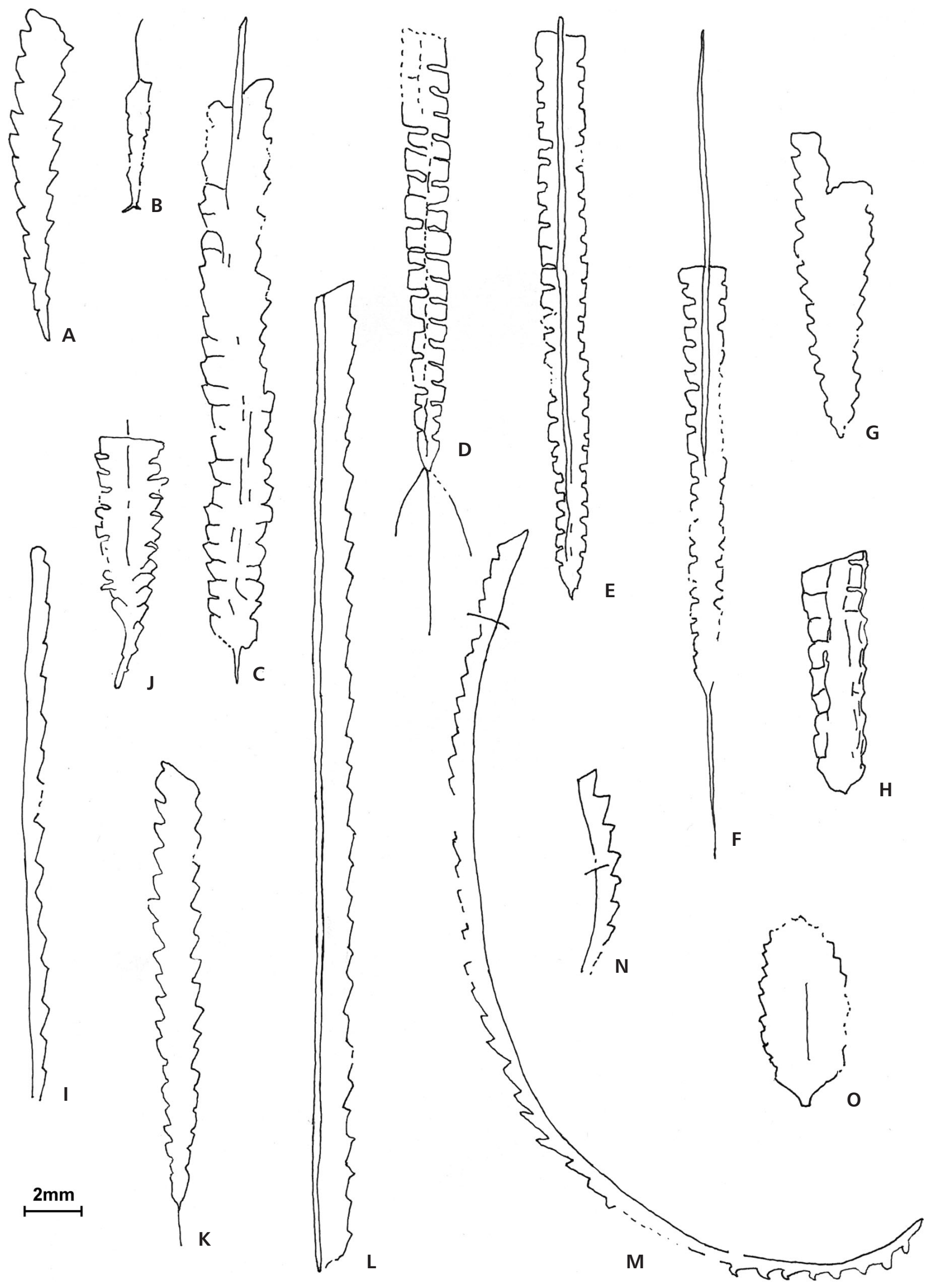


lanceolatus characterizes the lower and middle part of the biozone in peri-Gondwanan Europe (but was found also in the upper part of the biozone in Jordan; Loydell 2007), and Normalograptus trifilis and Cystograptus ancestralis the middle part. This Akidograptus ascensus-Parakidograptus acuminatus Biozone has been identified also in other regions in Europe such as S Portugal (Piçarra et al. 1995), NW Spain, Austria, E Serbia, Bulgaria (see references in Štorch 1996), and Poland (Masiak et al. 2003), although with a smaller number of species. Recently, Loydell (2007) noted that the Jordan Akidograptus ascensus-Parakidograptus acuminatus assemblages are similar to those of peri-Gondwanan Europe, but with a few "North African" species also present.

Bourahrouh (2002) reported chitinozoans of the Spinachitina fragilis Biozone from the phtanites of the Akidograptus ascensus-Parakidograptus acuminatus Biozone of Les Fresnaies.

\section{Cystograptus vesiculosus Biozone}

The Cystograptus vesiculosus Biozone of the middle part of the Rhuddanian has been identified on both sides of the fault that cuts through the succession, on the NE side between levels 30 and 31 (Fig. 3). The strata on either side of the fault show identical lithologies with similar graptolite assemblages, the southwestern block being slightly upthrown (Fig. 2). Between levels 30 and 31, the phtanites have yielded Cystograptus vesiculosus (Nicholson) (Fig. 4H), Normalograptus angustus?, Normalograptus cf. medius (Törnquist), Normalograptus normalis, Neodiplograptus sp., Dimorphograptus confertus (Nicholson) and "Monograptus" austerus austerus Törnquist.

The species identified on the SW side of the fault include Cystograptus vesiculosus, Atavograptus atavus (Jones) (Fig. 4I), Normalograptus normalis, Neodiplograptus elongatus?, Dimorphograptus confertus (Fig. 4J) Rhaphidograptus extenuatus (Elles \& Wood) and "Monograptus" a. austerus. Atavograptus atavus occurs in the lower part of the Cystograptus vesiculosus Biozone, as is the case in Bohemia (Štorch 1994), which correlates with the Atavograptus atavus Biozone of Great Britain (Rickards 1976) and Arctic Canada (Melchin 1989). In the middle part of the biozone, we have identified a distal fragment questionably attributed to Huttagraptus acinaces (Törnquist).
The assemblages listed above are similar to those found, at the same level, in the Portuguese and Spanish parts of the Ossa Morena Zone (Robardet et al. 1998), in the West Asturian-Leonese Zone of Spain and in Catalonia (see references in Robardet \& Gutiérrez-Marco 2002), Bohemia (Štorch 1994), Poland (Masiak et al. 2003) and also in Jordan (Loydell 2007), here with "North African" species also present. In these regions, as well as at Les Fresnaies, several monograptids found by Koren' \& Bjerreskov (1997) in Bornholm and in the Urals are unknown.

\section{Coronographus cyphus Biozone}

In the interval between levels 32 and 34 we have found distal fragments that could possibly belong to Coronograptus cyphus (Lapworth) but could equally well be fragments of other monograptids such as "Monograptus" austerus austerus, "M." austerus vulgaris or "M." difformis (Törnquist), when tectonically deformed or not very well preserved. The species identified are Coronograptus cyphus? (Fig. 4L), Normalograptus normalis, Neodiplograptus thuringiacus (Kirste), Neodiplograptus sp. (cf. fezzanensis), Rhaphidograptus toernquisti (Elles \& Wood), Glyptograptus ex gr. tamariscus (Nicholson) (Fig. 4K), Pseudorthograptus obuti (Rickards \& Koren'), Campograptus cf. communis (Lapworth), "Monograptus" a. austerus and "M." a. vulgaris Hutt (Fig. 4M). This assemblage comprises most of the species known in other regions of north-Gondwanan Europe - e.g., Portugal and Spain (Robardet et al. 1998) and Bohemia (Štorch 1994). At Les Fresnaies, "M." a. vulgaris occurs in the upper part of the biozone (level 34) as in Bohemia.

\section{Demirastrites triangulatus-Demirastrites pectinatus Biozone}

The Demirastrites triangulatus-Demirastrites pectinatus Biozone of the lower part of the Aeronian begins $10 \mathrm{~cm}$ below level 35 and extends up to level 37 . The graptolite assemblage found in this interval includes Neodiplograptus thuringiacus, Normalograptus normalis, Normalograptus rectangularis? (McCoy), Rhaphidograptus toernquisti, Glyptograptus ex gr. tamariscus, Rivagraptus cf. cyperoides (Nicholson), Petalolithus ovatoelongatus (Kurck) (Fig. 4O),

Figure 5. Graptolites of the Demirastrites triangulatus-Demirastrites pectinatus (A, B), Pribylograptus leptotheca (L), Lituigraptus convolutus (C-J) and Stimulograptus sedgwickii (K, M-P) biozones. - A - Demirastrites triangulatus, MHNN.P. 053283. • B - Demirastrites pectinatus, MHNN.P. 053284. • C - Lituigraptus convolutus, MHNN.P. 053285. • D - Campograptus lobiferus, MHNN.P. 053286. • E - Rastrites peregrinus, MHNN.P. 053287. • F-Torquigraptus denticulatus, MHNN.P. 053288. • G - Monograptus mirificus, MHNN.P. 053289. • H - Petalolithus praecursor, MHNN.P. 053290. • I - Rivagraptus bellulus, MHNN.P. 053291. • J - Pristiograptus cf. regularis, MHNN.P. 053292. • K - Stimulograptus sedgwickii or Stimulograptus halli, MHNN.P. 053293. • L - Neodiplograptus thuringiacus, MHNN.P. 053294; M - Rastrites schaueri, MHNN.P. 053295. - N - Torquigraptus magnificus, MHNN.P. 053296. • O - Monograptus cf. mirus, MHNN.P. 053297. • P - Monograptus cf. pulcherrimus, MHNN.P. 053298. All $\times 5$. 
José Manuel Piçarra et al. • Graptolite faunas of the Llandovery "phtanites", Armorican Massif

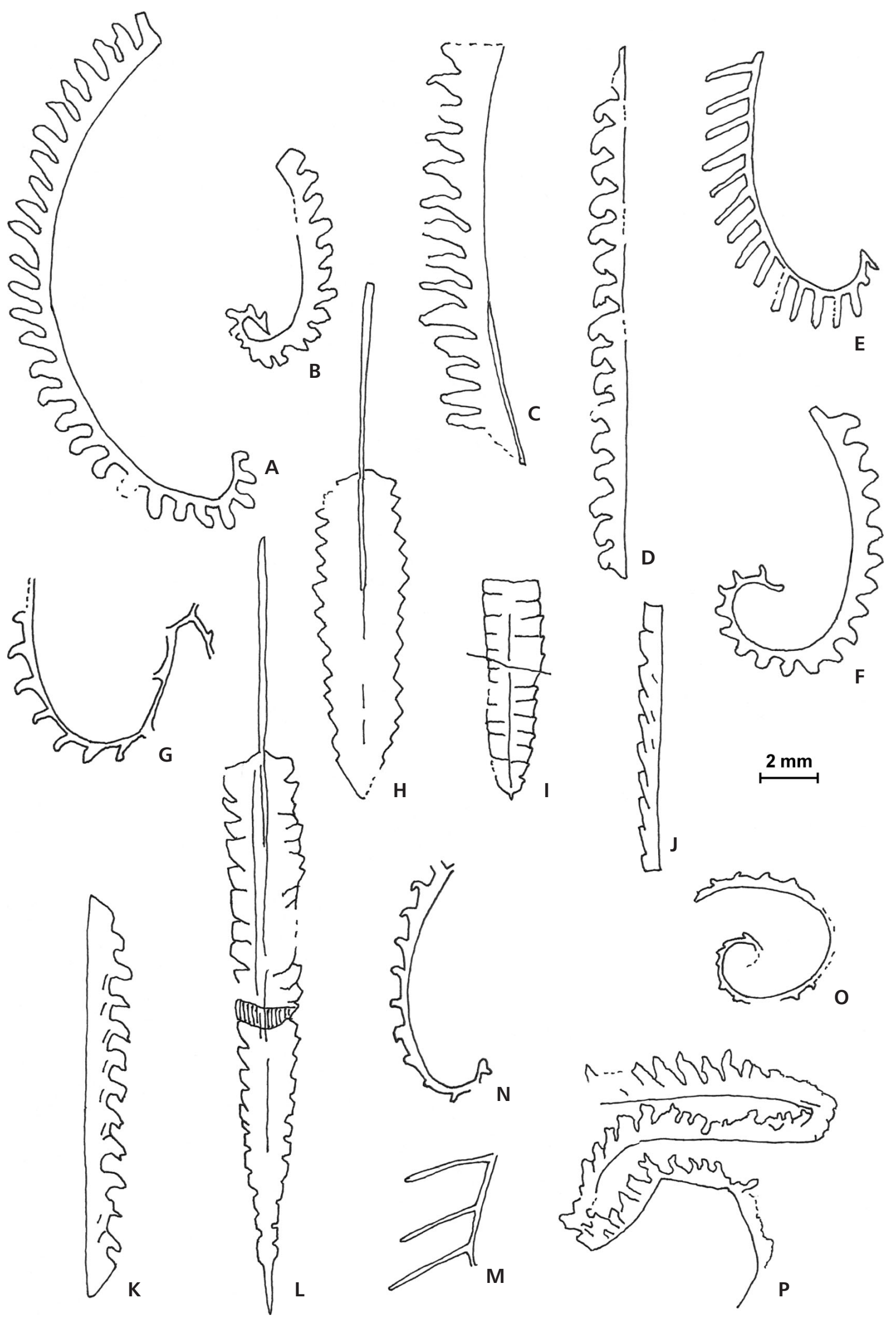


Demirastrites triangulatus (Harkness) (Fig. 5A), Demirastrites pectinatus (Richter) (Fig. 5B), Rastrites longispinus Perner, Campograptus communis, Coronograptus gregarius (Lapworth) (Fig. 4N), "Monograptus" austerus vulgaris and Lagarograptus sp.

Demirastrites pectinatus has been identified only in level 37, associated with Demirastrites triangulatus. The joint occurrence of the two index species is also known in Bohemia (Štorch 1994) and in the Portuguese part of the Ossa Morena Zone (Robardet et al. 1998). Although much less diverse, this assemblage resembles that which occurs (Štorch 1994) in the Barrandian region of the Czech Republic. Similar assemblages (with a higher or lower diversity) have been recognized also in other regions of Spain and Portugal (see references in Robardet et al. 1998, GutiérrezMarco \& Štorch 1998, Piçarra et al. 2006) and in Sardinia (Štorch \& Serpagli 1993). Demirastrites triangulatus was mentioned at Les Fresnaies and also in the Poligné-Pléchatel syncline (Philippot 1950, pp. 82, 111) but there was no illustration and we have not been able to see the material.

\section{Pribylograptus leptotheca Biozone}

After an initial study of the poorly preserved graptolites found in level 38, it was considered that they could indicate the "Monograptus" argenteus Biozone (Piçarra et al. 2002), but this conclusion is doubtful as neither "M". argenteus nor the other taxa characteristic of this biozone are present at Les Fresnaies. New samples have allowed identification of Neodiplograptus thuringiacus (Fig. 5L), Normalogratus normalis, Glyptograptus ex gr. tamariscus, Petalolithus praecursor Bouček \& Přibyl, Coronograptus gregarius, Campograptus sp., Lituigraptus richteri Perner, Rastrites peregrinus Barrande, "Monograptus" mirus Perner and Pristiograptus concinnus? (Lapworth).

The presence of Lituigraptus richteri in the level 38 and $0.35 \mathrm{~m}$ above, without the occurrence of Lituigraptus convolutus, suggest that this interval may be assigned to the Pribylograptus leptotheca Biozone. A similar situation was recognized in the locality of Tmaň of the Barrandian (Štorch 1998), where the two species do not coexist. The first appearance of Pribylograptus leptotheca occurs $0.35 \mathrm{~m}$ above the level 38, associated with Lituigraptus convolutus.

\section{Lituigraptus convolutus Biozone}

The Lituigraptus convolutus Biozone of the middle Aeronian extends between $0.35 \mathrm{~m}$ above level 38 and $0.5 \mathrm{~m}$ above level 41 . The graptolite assemblage found in this interval includes Neodiplograptus thuringiacus, Normalograptus normalis?, Normalograptus sp. (scalaris ?), Glyptograptus ex gr. tamariscus, Cephalograptus cometa cometa Bouček \& Přibyl, Rivagraptus bellulus (Törnquist) (Fig. 5I), Pseudorthograptus insectiformis (Nicholson), Metaclimacograptus hughesi (Nicholson), Petalolithus cf. minor (Elles), Petalolithus praecursor (Fig. 5H), Petalolithus folium? (Hisinger), Coronograptus gregarius, Coronograptus maxiculus Štorch, Campograptus lobiferus (McCoy) (Fig. 5D), Campograptus millepeda (McCoy), Campograptus sp., Lituigraptus convolutus (Fig. 5C), Lituigraptus richteri, Torquigraptus denticulatus Törnquist (Fig. 5F), Torquigraptus decipiens Törnquist, Rastrites approximatus Perner, R. peregrinus (Fig. 5E), Monograptus respectabilis, Monograptus mirificus (Fig. 5G), "Monograptus " mirus, "Monograptus" limatulus? Törnquist, Monoclimacis cf. crenularis (Lapworth), Pristiograptus concinnus, Pristiograptus cf. regularis (Törnquist) (Fig. 5J), Pribylograptus leptotheca (Lapworth) and Streptograptus sp.

The lower part of the biozone is characterized by the presence of Petalolithus praecursor, Coronograptus gregarius, Coronograptus maxiculus, Campograptus millepeda and Lituigraptus richteri; the upper part has yielded Cephalograptus cometa cometa, Rivagraptus bellulus, Torquigraptus denticulatus and Torquigraptus decipiens.

This assemblage is rather similar to that described from Bohemia by Štorch (1994), but it contains a smaller number of identified species; however, it is more diverse than those found in other regions of SW Europe, such as the Iberian Peninsula (Robardet et al. 1998, Gutiérrez-Marco \& Štorch 1998) and SW Sardinia (Štorch \& Serpagli 1993), or in Saudi Arabia (Zalasiewicz et al. 2007). L. convolutus was reported by Philippot (1950, p. 82), but without illustration.

\section{Stimulograptus sedgwickii Biozone}

The Stimulograptus sedgwickii Biozone of the upper Aeronian, represented here by $40 \mathrm{~cm}$ of strata, begins $10 \mathrm{~cm}$ below level 42 and extends up to level 43. In the first study (Piçarra et al. 2002), it was considered that these beds were situated in the basal part of the Telychian, but this cannot be confirmed.

Identified taxa are: Normalograptus? sp., Glyptograptus sp., Cephalograptus cometa extrema Bouček \& Přibyl, Metaclimacograptus sp., Petalolithus sp., Rastrites cf. gracilis, Rastrites schaueri Štorch \& Loydell (Fig. 5M), Torquigraptus magnificus Přibyl \& Münch (Fig. 5N), Lituigraptus urceolus, Monograptus cf. marri Perner, Monograptus cf. mirus (Fig. 5O), Monograptus cf. pulcherrimus Manck (Fig. 5P), Spirograptus andrewsi (Sherwin), Stimulograptus sedgwickii (Portlock) or Stimulograptus halli (Fig. 5K), Pristiograptus sp., Streptograptus sp. and Paradiversograptus? sp.

The presence of the index species is not confirmed because the specimens could possibly belong to this species but could equally well be fragments of Stimulograptus halli. 
The assemblage listed above, although less diverse, is similar to that of the Barrandian in Bohemia (Štorch 1994, 2001).

Cephalograptus cometa extrema and Torquigraptus magnificus occur only in the lowermost part of the interval. The presence of T. magnificus may indicate the lower part of the biozone, from which it is known in the Barrandian area (Štorch 2001) and in the Ossa Morena Zone in Spain (Štorch, pers. comm.).

Lituigraptus urceolus, Rastrites cf. gracilis, Monograptus cf. pulcherrimus and M. cf. marri, appear only in the upper part of the interval and characterize the middle and upper parts of the biozone, as it occurs in Bohemia.

In western mid-Wales, outside the north-Gondwanan regions, Stimulograptus sedgwickii occurs also in strata from the overlying Stimulograptus halli Biozone, through to the top of the Stimulograptus utilis Subzone (Loydell 1991).

In the Armorican Massif, Philippot (1950) mentioned (without any illustration) the presence of "Monograptus Sedgwickî' at Les Fresnaies (p. 82), at Réminiac (p. 101), in the Poligné-Pléchatel syncline (pp. 106, 111) and in the Ménez-Belair area (pp. 129, 147 and 154), in association with other taxa of various ages.

\section{Stimulograptus halli Biozone?}

The Stimulograptus halli Biozone may correspond to the uppermost part of the studied sequence, $0.30 \mathrm{~m}$ above level 43 . Like in the preceding biozone, it is difficult to distinguish between Stimulograptus halli from Stimulograptus sedgwickii. Besides, the graptolite assemblage found in this interval is poorly preserved and includes Petalolithus sp., Metaclimacograptus sp., Monograptus cf. marri, Stimulograptus halli and Pristiograptus sp.

This biozone is only individualized in the western mid-Wales, above the Stimulograptus sedgwickii Biozone (Loydell 1991). In Bohemia, S. halli appears at the base of the Rastrites linnaei Biozone (Štorch 1994), and the same situation occurs in Spain (Ossa Morena Zone and Western Iberian Cordillera) (Jaeger \& Robardet 1979, GutiérrezMarco \& Štorch 1998).

\section{Final remarks}

Euxinic black shale-black chert sedimentation started at the beginning of the Silurian and continued throughout the whole Rhuddanian and Aeronian, and most probably later, but this cannot be documented in the studied locality because of structural disturbances that interrupt the succession.

The condensed character of the euxinic succession, without any influx of coarser siliclastic material, observed at Les Fresnaies clearly differs from that of the Silurian successions that occur in the Mid-North Armorican Domain.
The sedimentological characteristics and the specific composition of the graptolite assemblages identified at Les Fresnaies are strongly similar to those of the coeval successions that occur in several parts of north-Gondwanan Europe, such as Thuringia, Bohemia, the Ossa Morena Zone of the Iberian Peninsula and Sardinia. It can be considered that, in Early Silurian North-Gondwana, all of these regions were situated in a distal offshore position, beyond any siliciclastic influx coming from emerged land areas.

\section{Acknowledgments}

We thank Petr Štorch for helpful discussions about several points concerning the biostratigraphy of the graptolite assemblages, and the referees David Loydell and Petr Štorch for useful remarks and suggestions.

The results presented here were obtained after field work in 1997-1999 and in 2002 within a Scientific Cooperation Program between Portugal (ICCTI and GRICES) and France (Ambassade de France au Portugal).

\section{References}

BARROIS, C. 1892. Mémoire sur la distribution des Graptolites en France. Annales de la Société Géologique du Nord 20, 75-191.

BourahrouH, A. 2002. Chitinozoaires et palynomorphes de l'Ordovicien Supérieur nord-gondwanien: impact de la glaciation ashgillienne. 300 pp. Thèse de Doctorat, Université Rennes I (No. d'ordre 2602), Rennes.

Chen, X., Zhang, Y.D., YU, G.H. \& LIU, X. 2007. Latest Ordovician and earliest Silurian graptolites from northwestern Zhejiang, China. Acta Palaeontologica Sinica 46 (Supplement), 77-82.

Cogné, J. 1974. Le Massif Armoricain, 105-161. In DEBELMAS, J. (ed.) Géologie de la France I . Doin, Paris.

DAVY, L.P. 1895. Contribution à l'étude géologique des environs de Chalonnes-sur-Loire (Maine-et-Loire). Terrain Silurien supérieur. Bulletin de la Société des Sciences Naturelles de l'Ouest de la France 5, 199-204.

DAVY, L.P. 1906. Ce que l'on croit savoir aujourd'hui sur la constitution géologique des environs de Chalonnes-sur-Loire. Bulletin de la Société d'Etudes Scientifiques d'Angers 35(1905), 91-125.

DUBREUIL, M. 1980. Hypothèse sur la mise en place, au Dinantien, du complexe du Tombeau Leclerc (Bassin d'Ancenis, sud-est du Massif armoricain) sous forme d'un olistostrome. Conséquences géodynamiques. Comptes Rendus de l'Académie des Sciences, Paris, Série D 290, 1455-1458.

DubreuIL, M. 1986. Evolution géodynamique du Paléozö̈que ligérien (Massif Armoricain). 258 pp. Thèse de Doctorat d'Etat, Université de Nantes, Nantes.

Dubreuil, M., Cavet, P., Blaise, J., Estéoule-ChouX, J., GRUET, M. \& LARDEUX, H. 1989. Notice explicative de la feuille Saint-Mars-la-Jaille à 1/50.000 No. 421.73 pp. Bureau de Recherches Géologiques et Minières, Orléans.

GuTIÉRREZ-MARCO, J.C. \& ŠTORCH, P. 1998. Graptolite biostratigraphy of the Lower Silurian (Llandovery) shelf depos- 
its of the Western Iberian Cordillera, Spain. Geological Magazine 135, 71-92. DO1 10.1017/S0016756897007802

JAEGER, H. 1976. Das Silur und Unterdevon vom thüringischen Typ in Sardinien und seine regionalgeologische Beteudung. Nova Acta Leopoldina, neue Folge 45(224), 263-299.

JAEGER, H. 1988. The Ordovician-Silurian boundary in the Saxothuringian Zone of the Variscan Orogen, 101-106. In COCKS, L.R.M. \& RICKARDS, R.B. (eds) A Global Analysis of the Ordovician-Silurian boundary. Bulletin of the British Museum (Natural History), Geology 43.

JAEGER, H. \& RobARdeT, M. 1979. Le Silurien et le Dévonien basal dans le Nord de la Province de Séville (Espagne). Géobios 12(5), 687-714. DOI 10.1016/S0016-6995(79)80097-2

KOREN', T.N. \& BJERRESKOV, M. 1997. Early Llandovery monograptids from Bornholm and the southern Urals: taxonomy and evolution. Bulletin of the Geological Society of Denmark 44, 1-43.

KoreN', T. \& SobOLEVSKAYA, R.F. 1983. Graptolity, 97-160. In SOKOLOV, B.S., KOREN', T. \& NIKITIN, I.F. (eds) The Ordovician and Silurian boundary in the Northeast of the USSR Nauka, Leningrad. [in Russian with English summary]

LARdeuX, H. \& CAVET, P. 1994. Paleozoic of the Ligerian Domain, 152-156. In KEPPIE, J.D. (ed.) Pre-Mesozoic Geology in France and related Areas. Springer-Verlag, Berlin \& Heidelberg.

LaRdeuX, H., Chauvel, J.J., HENRY, J.L., MORZADEC, P., PARIS, F., RACHEBOEUF, P. \& ROBARDET, M. 1977. Evolution géologique du Massif Armoricain au cours des temps ordoviciens, siluriens et dévoniens. Colloques internationaux du C.N.R.S. 243, 181-192.

LOYDELL, D.K. 1991. The biostratigraphy and formational relationships of the upper Aeronian and lower Telychian (Llandovery, Silurian) formations of western mid-Wales. Geological Journal 26, 209-244. DOI 10.1002/gj.3350260304

LOYDELL, D.K. 2007. Graptolites from the Upper Ordovician and Lower Silurian of Jordan. Special Papers in Palaeontology 78, 1-66.

Masiak, M., Podhalanska, T. \& StemPien-SaleK, M. 2003. Ordovician-Silurian boundary in the Bardo Syncline, Holy Cross Moutains, Poland - new data and fossil assemblages and sedimentary sucession. Geological Quarterly 47(4), 311-330.

MELCHIN, M.J. 1989. Llandovery graptolite biostratigraphy and paleobiogeography, Cape Phillips Formation, Canadian Arctic Islands. Canadian Journal of Earth Sciences $26,1726-1746$.

MELCHIN, M.J. 2004. Restudying a global stratotype for the base of the Silurian: a report the members of the Subcommission on Silurian Stratigraphy. Silurian Times 12, 12-13.

MU, E. 1988. The Ordovician-Silurian boundary in China, 117-131. In COCKS, L.R.M. \& RICKARDS, R.B. (eds) A Global Analysis of the Ordovician-Silurian boundary. Bulletin of the British Museum (Natural History), Geology 43.

PARIS, F. \& RoBARDET, M. 1977. Paléogéographie et relations ibéro-armoricaines au Paléozoïque anté-Carbonifère. Bulletin de la Société géologique de France 19(7),1121-1126.

PARIS, F. \& ROBARDET, M. 1994. The Variscan Orogeny in the Armorican Massif. Introduction, 133-135. In KEPPIE, J.D. (ed.) Pre-Mesozoic Geology in France and Related Areas. Springer-Verlag, Berlin \& Heidelberg.

PHILIPPOT, A. 1950. Les Graptolites du Massif Armoricain. Etude stratigraphique et paléontologique. Mémoires de la Société géologique et minéralogique de Bretagne 11, 1-295.

PiçARrA, J.M., GutiéRREZ-MARCO, J.C., SÁ, A.A., MEIRELES, C.
\& GonZÁleZ-ClaviJo, E. 2006. Silurian graptolite biostratigraphy of the Galicia - Trás-os-Montes Zone (Spain and Portugal). G.F.F. 128(2), 185-188.

Piçarra, J.M., Robardet, M., Bourahrouh, A., Paris, F., PEREIRA, Z., LE MENN, J., GOURVENNEC, R., OLIVEIRA, J.T. \& LARDEUX, H. 2002. Le passage Ordovicien-Silurien et la partie inférieure du Silurien (Sud-Est du Massif armoricain, France). Comptes Rendus Géoscience 334, 1177-1183.

DOI 10.1016/S1631-0713(02)01864-3

PiçARRA, J.M., ŠTORCh, P., GutiÉRREZ-MARCO, J.C. \& OliVEIRA, J.T. 1995. Characterization of the Parakidograptus acuminatus graptolite Biozone in the Silurian of the Barrancos region (Ossa Morena Zone, south Portugal). Comunicaçôes do Instituto Geológico e Mineiro 81, 3-8.

RICKARDS, R.B. 1976. The sequence of Silurian graptolite zones in the British Isles. Geological Journal 11, 153-188.

RIVIÈRE, L.M. 1977. Le Culm frano-dinantien du synclinal d'Ancenis (SE du Massif armoricain) au N de la Loire. Bulletin de la Société géologique et minéralogique de Bretagne, C 9(1), 19-57.

Robardet, M., Verniers, J., FeIST, R. \& PARIS, F. 1994. Le Paléozoïque anté-varisque de France, contexte paléogéographique et géodynamique. Géologie de la France 1994(3), 3-31.

RoBARDET, M. \& GUTIÉRREZ-MARCO, J.C. 2002. Silurian, 51-66. In Gibbons, W. \& Moreno, T. (eds) The Geology of Spain. Geological Society of London.

ROBARDET, M., PIÇARRA, J.M., ŠTORCH, P., GUTIÉRREZ-MARCO, J.C. \& SARMIENTO, G.N. 1998. Ordovician and Silurian stratigraphy and faunas (graptolites and conodonts) in the Ossa Morena Zone of the SW Iberian Peninsula (Portugal and Spain). Temas Geológico-Mineros ITGE 23, 289-318.

ŠTORCH, P. 1986. Ordovician-Silurian boundary in the Prague Basin (Barrandian area, Bohemia). Sborník geologických věd, Geologie 41, 69-103.

ŠTORCH, P. 1994. Graptolite biostratigraphy of the Lower Silurian (Llandovery and Wenlock) of Bohemia. Geological Journal 29, 137-165.

ŠTORCH, P. 1996. The basal Silurian Akidograptus ascensus-Parakidograptus acuminatus Biozone in peri-Gondwanan Europe: graptolite assemblages, stratigraphical ranges and palaeobiogeography. Věstník Českého geologického ústavu 71, 177-188.

ŠTORCH, P. 1998. Graptolites of the Pribylograptus leptotheca and Lituigraptus convolutus biozones of Tmaň (Silurian, Czech Republic). Journal of the Czech Geological Society 43(4), 209-272.

ŠTORCH, P. 2001. Graptolites, stratigraphy and depositional setting of the middle Llandovery (Silurian) volcanic-carbonate facies at Hýskov (Barrandian area, Czech Republic). Bulletin of the Czech Geological Survey 76(1), 55-76.

ŠTORCH, P. 2006. Facies development, depositional settings and sequence stratigraphy across the Ordovician-Silurian boundary: a new perspective from the Barrandian area of the Czech Republic. Geological Journal 41, 163-192. DOI 10.1002/gj.1038

ŠTORCH, P. \& SERPAGLI, E. 1993. Lower Silurian graptolites from southwestern Sardinia. Bollettino della Società Paleontologica Italiana 32(1), 3-57.

Zalasiewicz, J., Williams, M., Miller, M., Page, A. \& BLACKETT, E. 2007. Early Silurian (Llandovery) graptolites from Central Saudi Arabia: first documented record of Telychian faunas from the Arabian Peninsula. GeoArabia 12(4), 15-36. 